\title{
CHANGES IN MOTOR SKILLS OF CHLDREN WHO TRAIN SPORTS SWIMMING AT THE INITIAL STAGE OF SCHOOL EDUCATION (IN AN ANNUAL TRAINING CYCLE)
}

\author{
Paweł Eider, A, B, C, D Krzysztof Wilk, A, B, C, D Michał Tarnowski, A, B, C, D \\ Robert Terczyński ${ }^{A, B}$, C, D
}

Faculty of Physical Culture and Health Promotion, University of Szczecin, Poland

${ }^{\text {A }}$ Study Design; ${ }^{\mathrm{B}}$ Data Collection; ${ }^{\mathrm{C}}$ Statistical Analysis; ${ }^{\text {D Manuscript Preparation }}$

\author{
Address for corpespondence: \\ Paweł Eider \\ University of Szczecin, Faculty of Physical Culture and Health Promotion, \\ Al. Piastów 40b, building 6 \\ 71-065 Szczecin, Poland \\ E-mail: pawel.eider@univ.szczecin.pl
}

\begin{abstract}
Ahstract This paper presents an empirical approach to the changes in motor skills of children who train sports swimming at the initial stage of school education in an annual training cycle. Swimming belongs to the disciplines in which training starts at the age of 6-7. The proper selection of candidates to train certain disciplines is a complex process as they should be chosen from a large population of children, both girls and boys, having specific somatic and motor characteristics which, developed in the long-term, will enable them to achieve sports mastery. The aim of the research was to define which changes in motor skills occur in girls who train sports Aim: swimming in an annual training cycle. The Subject group consisted of 85 girls aged 7 who attended four elementary schools in Szczecin, Poland. 36 of them belonged to the Swimmers group and they were all members of the Municipal Swimming Club (MKP) in Szczecin. The Control group consisted of 49 girls who attended the same elementary schools. All subjects took part in two examinations (carried out in the school year 2009/2010. Physical ability tests were conducted in gyms. Motor skills were assessed with EUROFIT Test Battery which is the most reliable and accurate tool according to scientific research. The research revealed changes in both groups (Sw, C) in terms of all eight tests. Examination II proved statistically significant improvement of results in both groups (Sw, C) in comparison to Examination I. Changes between Examination I and Examination II results were most visible in the Swimmers groups in terms of balance, agility, static strength, functional strength and agility run. Changes between Examination I and Examination II were similar in both groups (Sw, C) in terms of speed of limb movement, explosive strength and torso strength. Progressive changes in motor skill of subjects are a positive phenomenon in the physical development of a child. Swimming training resulted significantly in positive changes in terms of motor skills of subject who were at the initial stage of swimming trainings, compared to their non-training peers. Participation in organized, regular sports classes results in the development of motor (physical) skills of children.
\end{abstract}

Key WOrlls selection, motor skills, swimming, girls, analysis 


\section{Introduction}

Current world-class athletes' bodies display specific characteristics which result from the sports discipline they train. They are of certain age and have certain parameters: somatic, motor and functional. Their size and quality result in a so-called 'champion model' (Kosmol, 1997; Karpiński, Opyrchał, 2008; Socha, 2008; Kolbowicz, 2012) Continuous observation over the years and analysis of characteristics of the best athletes, Olympic Games medalists, help trainers make changes in their training programs in order to achieve the model champion qualities in their trainees (Karpiński, Opyrchał, 2008).

Knowledge of model parameters (qualities) of world's best athletes is used by trainers during selection of prospective athletes for a given sports discipline, and subsequently at various stages of sports selection. It is advisable to seek future champions based on their specific qualities (including motor skills), which - developed over the years of trainings - may lead to championship in sports (Chomiak, Migasiewicz, 1998; Cięszczyk, 2005, 2008; Opyrchał, Karpiński, Sachnowski, 2005). Effects of trainers' work depend largely on a correct selection process for sports swimming, and on professional, multi-step selection at a later stage (Eider, 2014).

The aim of this study was to determine what changes in motor skills occurred in girls who trained sports swimming during a 1-year training cycle.

\section{Material and research methods}

Subject group consisted of 85 girls aged 7 (1st grade of elementary school) who attended four elementary schools in Szczecin, Polamd. 36 of them belonged to the Swimmers group. All girls were members of the Municipal Swimming Club (MKP) in Szczecin. Before selecting the girls for swimming classes, they did not participate in any systematic swimming training. The Control group consisted of 49 girls who attended the same elementary schools. The Control group members were selected based on the age of the Swimmers group members, with 3 months' precision; all subjects attended the same grade (1 ${ }^{\text {st }}$ grade of elementary school). Children from the Control group did not participate in any sports/recreation classes. All subjects took part in two examinations (Table 1), carried out in the 2009/2010 academic year among 1 ${ }^{\text {st }}$ graders of Elementary School no. 51, 55, 56 and 62 in Szczecin (five swimming groups and four control groups) Examination I was conducted in September 2009, immediately after

Table 1. Number of girls in Swimmers and Control groups during examinations

\begin{tabular}{|c|c|c|c|c|}
\hline \multirow{2}{*}{ School } & \multirow{2}{*}{ Group } & \multirow{2}{*}{ Class number } & \multicolumn{2}{|c|}{ Study } \\
\hline & & & I & II \\
\hline \multirow{4}{*}{ El. Sch. 51} & Sw & $1 \mathrm{a}$ & 9 & 9 \\
\hline & Sw & $1 b$ & 8 & 8 \\
\hline & $C$ & $1 c$ & 12 & 12 \\
\hline & C & $1 d$ & 11 & 11 \\
\hline El. Sch. 51 & Sw & $1 \mathrm{a}$ & 10 & 10 \\
\hline \multirow{2}{*}{ El. Sch.56 } & Sw & $1 a$ & 5 & 5 \\
\hline & $C$ & $1 b$ & 11 & 11 \\
\hline El. Sch. 62 & Sw & $1 a$ & 4 & 4 \\
\hline El. Sch. 56 & $C$ & $1 \mathrm{c}$ & 15 & 15 \\
\hline Total & & & 85 & 85 \\
\hline
\end{tabular}

El. Sch. - Elementary School, Sw - Swimmers, C - Control. 
selection of Swimmers and Control groups (1st graders), while Examination II took place in June 2010, i.e. at the end of the $1^{\text {st }}$ grade. The analysis included only those children who participated in both examinations.

Physical ability tests were conducted in gyms and were preceded by standard warm-up for all children (7-8 minutes). The tests were as simple as possible and required minimal equipment. The most reliable and accurate indirect tests were used (Szopa, Chwała, Rychlewicz,1998). Motor skills were assessed with eight tests of the EUROFIT Test Battery (Grabowski, Szopa, 1991):

1. Flamingo Balance Test - general balance - keeping balance while standing on one leg on a beam of certain dimensions.

2. Plate Tapping Test - speed of upper limb movements - touching quickly two purposefully placed plates with the preferred (stronger) hand.

3. Sit-and-Reach Test - flexibility - sitting and reaching forward as far as possible.

4. Standing Broad Jump Test - explosive leg power - broad jump from a standing position.

5. Handgrip Strength Test - static strength - gripping forcefully a dynamometer.

6. Sit-Up Test - torso strength - lying on the back and doing max. number of sit-up within 30 seconds

7. Bent Arm Hang Test - functional strength - total time of maintaining the hang position with bent arms on a bar.

8. $10 \times 5$ m Shuttle Run Test - agility run - running with max. speed and changes of direction.

\section{Research results}

\section{Flamingo Balance Test - general balance}

In the analyzed groups of girls (Sw, C), average results of the Flamingo Balance Test during Examination I were identical. Examination II, however, revealed statistically better results of girls from the Swimmers group. Examination II proved statistically significant improvement of results in both groups (Sw, C) in comparison to Examination I (Table 2). In the Swimmers group, it was on average 3.4 attempts, while in the control group: 1.9 $(p<0.0001)$ (Figure 1).

Table 2. Descriptive characteristics of Flamingo Balance Test (general balance) in the Swimmers and Control groups

\begin{tabular}{|c|c|c|c|c|c|c|c|}
\hline & \multirow{2}{*}{ Distribution type } & \multicolumn{2}{|c|}{ Examination I } & \multicolumn{2}{|c|}{ Examination II } & \multicolumn{2}{|c|}{ Examination I vs. Examination II } \\
\hline & & Sw & C & Sw & C & Sw & C \\
\hline \multirow{5}{*}{ Girls } & $n$ & 36 & 49 & 36 & 49 & & \\
\hline & $\min -\max$ & $5.0-10.0$ & $6.0-9.0$ & $2.0-7.0$ & $3.0-9.0$ & & \\
\hline & mean & 8.0 & 8.0 & 4.0 & 6.0 & & \\
\hline & $\bar{X}(S D)$ & $7.7(1.1)$ & $7.7(1.1)$ & $4.3(1.2)$ & $5.8(1.2)$ & & \\
\hline & ss & \multicolumn{2}{|c|}{0.960} & \multicolumn{2}{|c|}{$<0.0001$} & $<0.0001$ & $<0.0001$ \\
\hline
\end{tabular}

Sw - Swimmers, C - Control, min - minimum value, max - maximum value, $\bar{X}$ - arithmetic mean, SD - standard deviation, ss - statistical significance. 
Girls

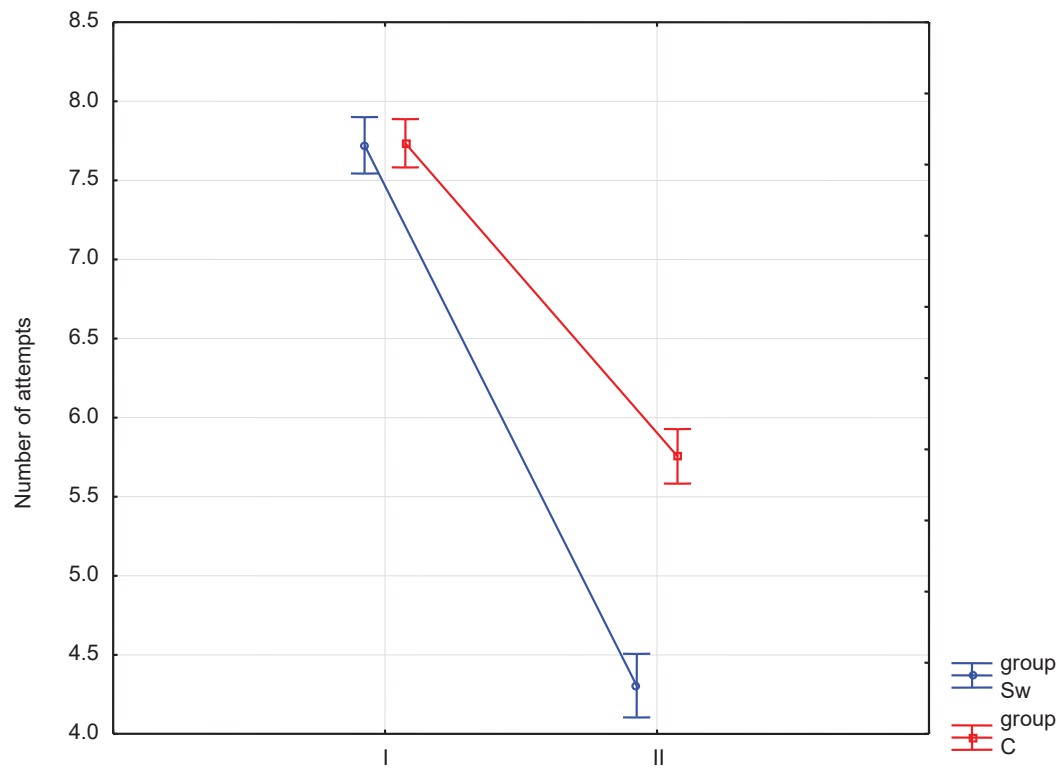

Figure 1. Changes in results of Flamingo Balance Test (general balance) in Swimmers (Sw) and Control (C) groups

\section{Plate Tapping Test - speed of upper limb movements}

Swimmers group displayed statistically insignificantly better results in Examinations I and II in terms of speed of upper limbs than the Control group. Examination II proved statistically significant improvement of results in both groups (Sw, C) in comparison to Examination I (Table 3). In the Swimmers group, it was on average $1.3 \mathrm{~s}$, while in the Control group it was $1.9 \mathrm{~s}(\mathrm{p}<918)$ (Figure 2).

Table 3. Descriptive characteristics of Plate Tapping Test (speed of upper limb movements) results in the Swimmers Group (Sw) and Control group (C).

\begin{tabular}{cccccccc} 
& \multirow{2}{*}{ Distribution type } & \multicolumn{3}{c}{ Examination I } & \multicolumn{2}{c}{ Examination II } & \multicolumn{2}{c}{ Examination I vs. Examination II } \\
\cline { 2 - 7 } & & $\mathrm{Sw}$ & $\mathrm{C}$ & $\mathrm{Sw}$ & $\mathrm{C}$ & $\mathrm{Sw}$ & $\mathrm{C}$ \\
\hline \multirow{4}{*}{ Girls } & 36 & 49 & 36 & 49 & & \\
& $\mathrm{n}$ & $15.0-31.1$ & $21.6-34.3$ & $14.8-29.5$ & $20.3-32.6$ & & \\
& min-max & 27.6 & 26.9 & 25.8 & 25.7 & & $<0.0001$ \\
\hline
\end{tabular}

Sw - Swimmers, C - Control, min - minimum value, max - maximum value, $\bar{X}$-arithmetic mean, SD - standard deviation, ss - statistical significance. 


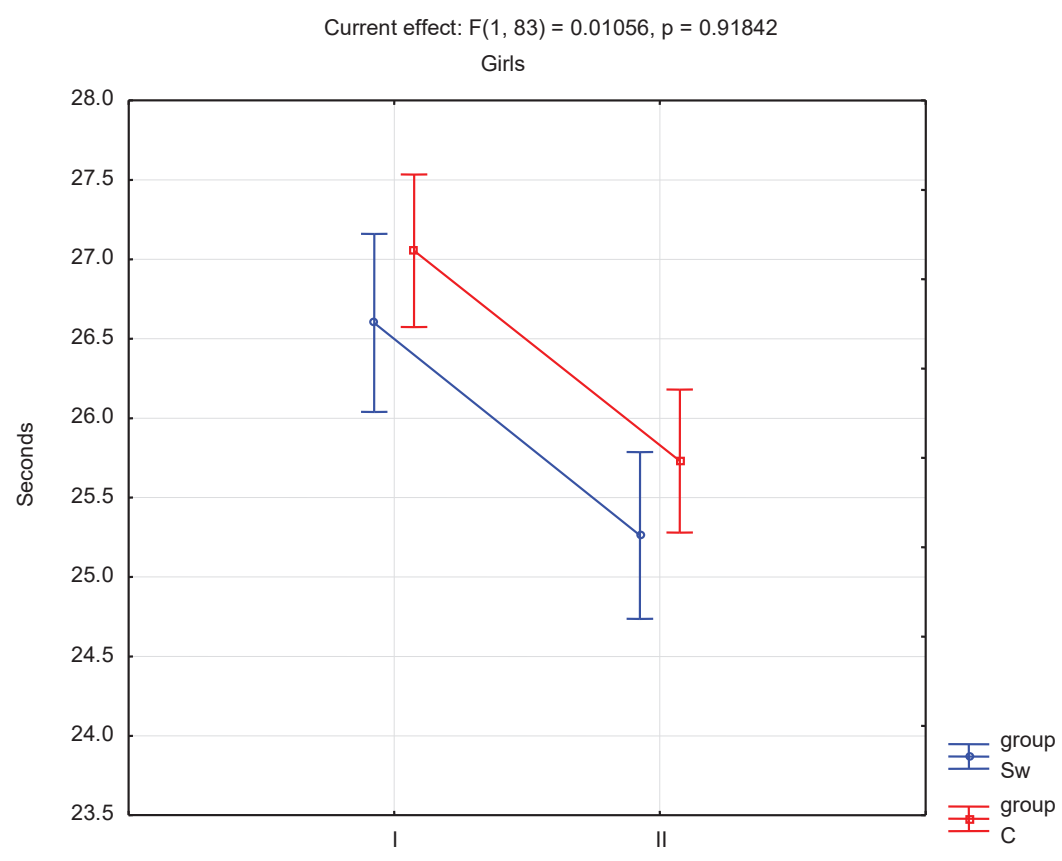

Figure 2. Changes in the results of Plate Tapping Test (speed of upper limb movements) in the Swimmers group (Sw) and Control group (C)

\section{Sit-and-Reach Test - flexibility}

Swimmers group displayed statistically significantly better results in Examination I and II in terms of torso flexibility. Examination II proved statistically significant improvement of results in both groups (Sw, C) in comparison to Examination I (Table 4). In the Swimming Group, it was on average $4.8 \mathrm{~cm}$, while in the Control group it was $3.9 \mathrm{~cm}(p=0.007)$ (Figure 3).

Table 4. Descriptive characteristics of Sit-and-Reach Test (flexibility) results in Swimmers (Sw) group and Control (C) group

\begin{tabular}{|c|c|c|c|c|c|c|c|}
\hline & \multirow{2}{*}{ Distribution type } & \multicolumn{2}{|c|}{ Examination I } & \multicolumn{2}{|c|}{ Examination II } & \multicolumn{2}{|c|}{ Examination I vs. Examination II } \\
\hline & & Sw & C & Sw & $\mathrm{C}$ & Sw & C \\
\hline \multirow{5}{*}{ Girls } & $n$ & 36 & 49 & 36 & 49 & & \\
\hline & $\min -\max$ & $-6.0-14.0$ & $-12.0-13.0$ & $-1.0-17.0$ & $-6.0-16.0$ & & \\
\hline & mean & 3.0 & 1.0 & 8.0 & 4.0 & & \\
\hline & $\bar{X}(S D)$ & $3.9(4.7)$ & $-0.5(5.6)$ & $8.7(4.0)$ & $3.4(5.4)$ & & \\
\hline & ss & \multicolumn{2}{|c|}{0.0002} & \multicolumn{2}{|c|}{$<0.0001$} & $<0.0001$ & $<0.0001$ \\
\hline
\end{tabular}

Sw - Swimmers, $C$ - Control, min - minimum value, max - maximum value, $\bar{X}$ - arithmetic mean, SD - standard deviation, ss - statistical significance. 
Girls

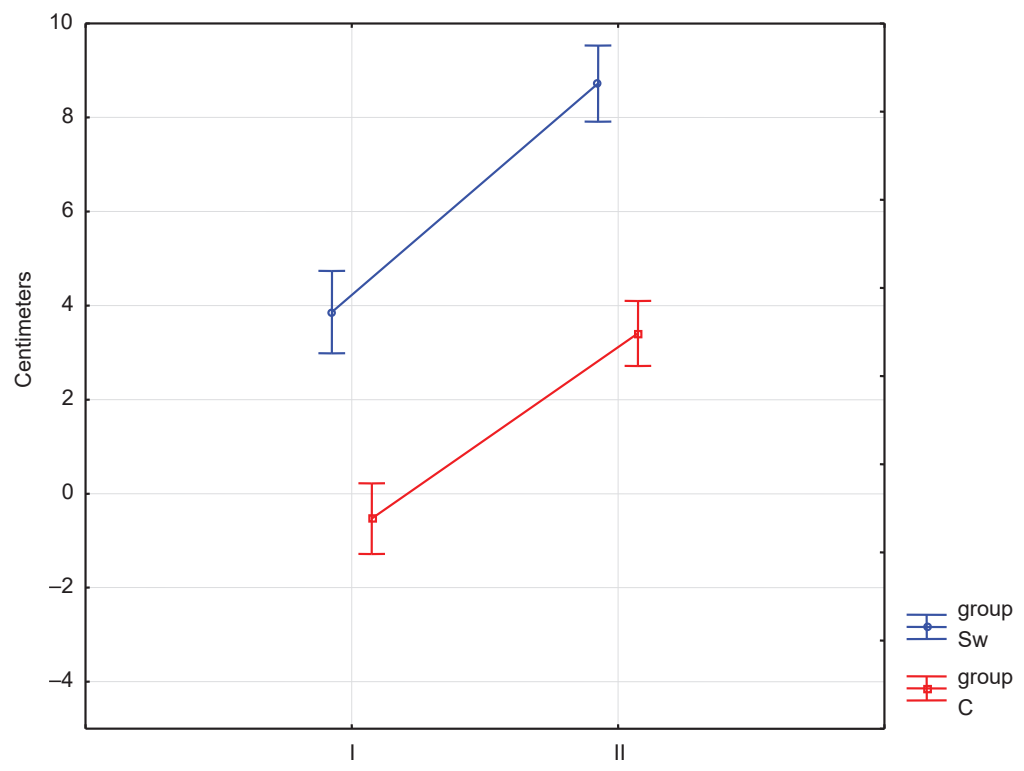

Figulp 3. Changes in results of the Sit-and-Reach Test (flexibility) in Swimmers (Sw) group and Control (C) group

\section{Standing Broad Jump Test - explosive leg power}

Swimmers group displayed statistically significantly better results in Examination I and II in terms of standing broad jumps. Examination II proved statistically significant improvement of results in both groups (Sw, C) in comparison to Examination I (Table 5). In the Swimmers group, it was on average $12.4 \mathrm{~cm}$, while in the control group it was $15 \mathrm{~cm}(p=0.123)$ (Figure 4).

Table 5. Descriptive characteristics of Standing Broad Jump Test (explosive leg power) results in the Swimmers (Sw) group and Control (C) group

\begin{tabular}{|c|c|c|c|c|c|c|c|}
\hline & \multirow{2}{*}{ Distribution type } & \multicolumn{2}{|c|}{ Examination I } & \multicolumn{2}{|c|}{ Examination II } & \multicolumn{2}{|c|}{ Examination I vs. Examination II } \\
\hline & & Sw & C & Sw & C & Sw & C \\
\hline & $\mathrm{n}$ & 36 & 49 & 36 & & & \\
\hline & $\min -\max$ & $55.0-132.0$ & $52.0-129.5$ & $64.5-146.0$ & $65.5-141.0$ & & \\
\hline \multirow[t]{3}{*}{ Girls } & mean & 105.8 & 94.0 & 117.5 & 108.0 & & \\
\hline & $\bar{X}(S D)$ & $105.4(14.8)$ & $91.4(16.9)$ & $117.8(15.7)$ & $106.4(16.5)$ & & \\
\hline & ss & \multicolumn{2}{|c|}{0.0002} & \multicolumn{2}{|c|}{0.002} & $<0.0001$ & $<0.0001$ \\
\hline
\end{tabular}

Sw-Swimmers, $C$ - Control, min - minimum value, max - maximum value, $\bar{X}$ - arithmetic mean, SD - standard deviation, ss - statistical significance. 


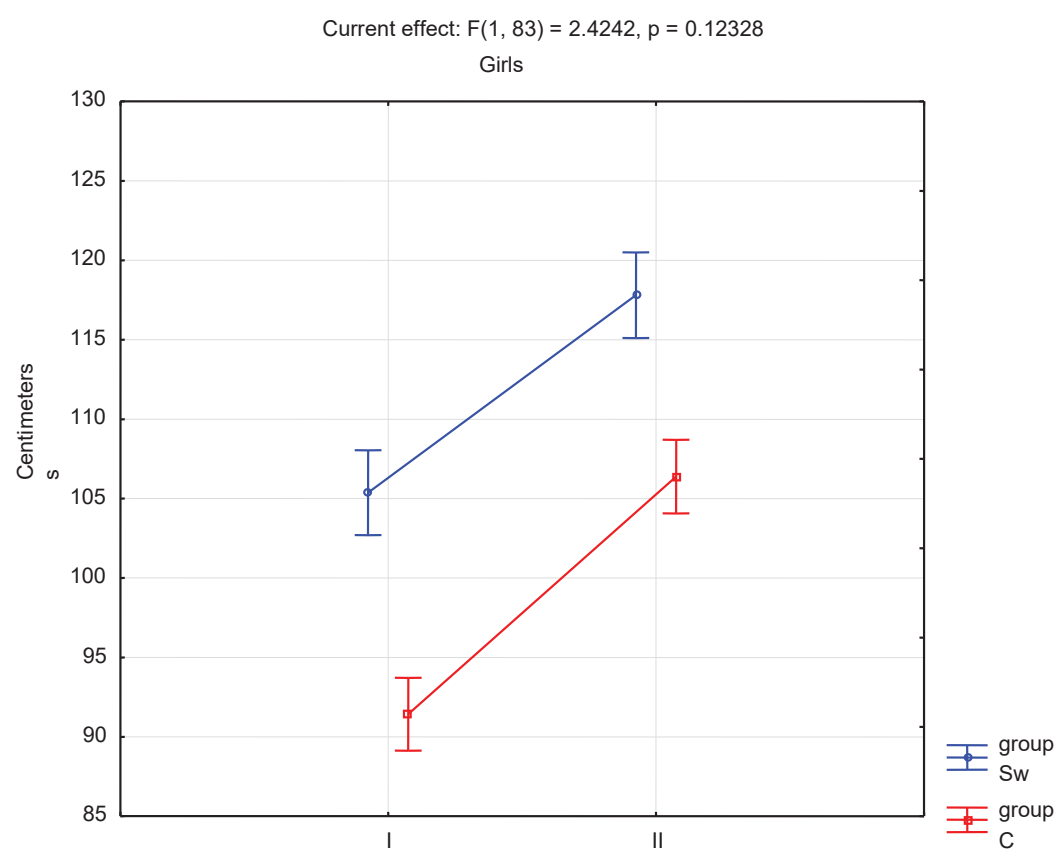

Figure 4. Changes in the results of Standing Broad Jump Test (explosive leg power) in the Swimmers (Sw) group and Control (C) group

\section{Handgrip Strength Test - static strength}

Swimmers (Sw) group displayed statistically insignificantly worse results in Examination I in terms of handgrip strength, in comparison to the Control (C) group. In Examination II, Swimmers group obtained statistically insignificantly better results than their peers from the Control group. Examination II proved statistically significant improvement of results in both groups (Sw, C) in comparison to Examination I (Table 6). In the Swimmers group it was 1.2 (psi)*, and in the Control group it was 0.7 (psi) ( $p<0.0001)$ (Figure 5).

Table 6. Descriptive characteristics of Handgrip Strength Test (static strength) results in the Swimmers (Sw) and Control (C) groups

\begin{tabular}{|c|c|c|c|c|c|c|c|}
\hline & \multirow{2}{*}{ Distribution type } & \multicolumn{2}{|c|}{ Examination I } & \multicolumn{2}{|c|}{ Examination II } & \multicolumn{2}{|c|}{ Examination I vs. Examination II } \\
\hline & & Sw & $\mathrm{C}$ & Sw & C & Sw & $\mathrm{C}$ \\
\hline & $\mathrm{n}$ & 36 & 49 & 36 & 49 & & \\
\hline & $\min -\max$ & $1.0-4.0$ & $0.5-5.0$ & $2.5-5.0$ & $1.0-5.5$ & & \\
\hline \multirow[t]{3}{*}{ Girls } & mean & 2.0 & 2.5 & 3.5 & 3.0 & & \\
\hline & $\bar{X}(S D)$ & $2.3(0.9)$ & $2.5(0.9)$ & $3.5(0.8)$ & $3.2(1.0)$ & & \\
\hline & ss & \multicolumn{2}{|c|}{0.309} & \multicolumn{2}{|c|}{0.220} & $<0.0001$ & $<0.0001$ \\
\hline
\end{tabular}

Sw - Swimmers, C - Control, min - minimum value, max - maximum value, $\bar{X}$ - arithmetic mean, SD - standard deviation, sS - statistical significance. 


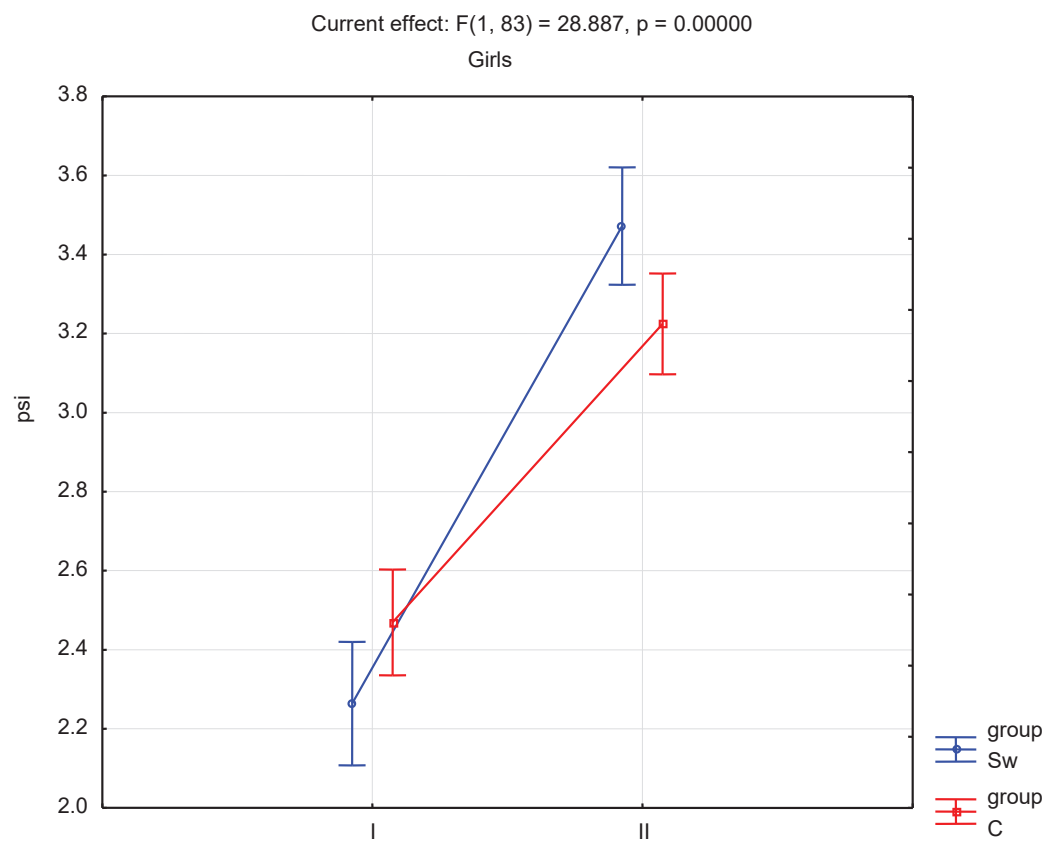

Figulp 5. Changes in Handgrip Strength Test (static strength) results in the Swimmers (Sw) and Control (C) groups

\section{Sit-Up Test - torso strength}

Swimmers (Sw) group displayed statistically insignificantly higher results in Examination I in terms of sit-ups, in comparison to the Control (C) group. Examination II revealed statistically better results of girls from the Swimmers group. Examination II proved statistically significant improvement of results in both groups (Sw, C) in comparison to Examination I (Table 7). In the Swimmers group, it was on average 6.5 (n), while in the Control group it was 5.6 (n) $(p=0.083)$ (Figure 6).

Table 7. Descriptive characteristics of Sit-Up Test (torso strength) results in the Swimmers (Sw) and Control (C) groups

\begin{tabular}{|c|c|c|c|c|c|c|c|}
\hline & \multirow{2}{*}{ Distribution type } & \multicolumn{2}{|c|}{ Examination I } & \multicolumn{2}{|c|}{ Examination II } & \multicolumn{2}{|c|}{ Examination I vs. Examination II } \\
\hline & & Sw & C & Sw & C & Sw & $C$ \\
\hline & $n$ & 36 & 49 & 36 & 49 & & \\
\hline & $\min -\max$ & $6.0-19.0$ & $1.0-21.0$ & $12.0-28.0$ & $7.0-26.0$ & & \\
\hline \multirow[t]{3}{*}{ Girls } & mean & 12.5 & 11.0 & 18.5 & 17.0 & & \\
\hline & $\bar{X}(S D)$ & $12.3(3.6)$ & $10.7(4.6)$ & $18.8(3.7)$ & $16.3(4.2)$ & & \\
\hline & ss & \multicolumn{2}{|c|}{0.078} & \multicolumn{2}{|c|}{0.006} & $<0.0001$ & $<0.0001$ \\
\hline
\end{tabular}

Sw - Swimmers, C - Control, min - minimum value, max - maximum value, $\bar{X}$-arithmetic mean, SD - standard deviation, ss - statistical significance. 
Girls

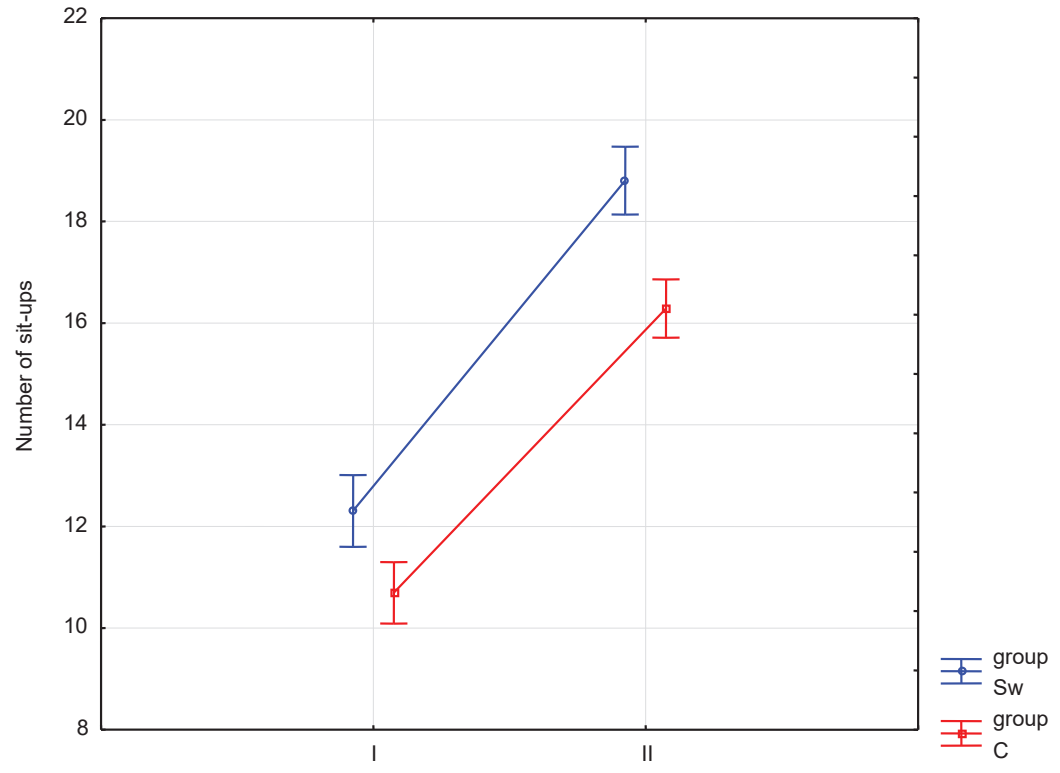

Figure 6. Changes in Sit-Up Test (torso strength) results in the Swimmers (Sw) and Control (C) groups

\section{Bent Arm Hang Test - functional strength}

Swimmers group displayed statistically significantly better results in Examination I and II in terms of bent arm hang. Examination II proved statistically significant improvement of results in both groups (Sw, C) in comparison to Examination I (Table 8). In the Swimming Group, it was on average $3.6 \mathrm{~s}$, while in the control group: $1.9 \mathrm{~s}$ $(p=0.0001)$ (Figure 7).

Table 8. Descriptive characteristics of Bent Arm Hang Test (functional strength) results in the Swimmers (Sw) group and Control (C) group

\begin{tabular}{cccccccc} 
& \multirow{2}{*}{ Distribution type } & \multicolumn{2}{c}{ Examination I } & \multicolumn{2}{c}{ Examination II } & \multicolumn{2}{c}{ Examination I vs. Examination II } \\
\cline { 3 - 7 } & & Sw (seconds) & C (seconds) & Sw (seconds) & C (seconds) & Sw & C \\
\hline \multirow{4}{*}{ Girls } & 36 & 49 & 36 & 49 & & \\
& min-max & $1.4-21.1$ & $0.9-20.0$ & $4.9-23.1$ & $3.6-22.2$ & & \\
& mean & 9.2 & 6.4 & 13.4 & 7.7 & & \\
$\bar{X}(\mathrm{SD})$ & $9.2(4.2)$ & $6.6(4.1)$ & $12.8(3.8)$ & $8.5(3.7)$ & $<0.0001$ & $<0.0001$ \\
\hline
\end{tabular}

SW - Swimmers, C - Control, min - minimum value, max - maximum value, $\bar{X}$ - arithmetic mean, SD - standard deviation, ss - statistical significance. 


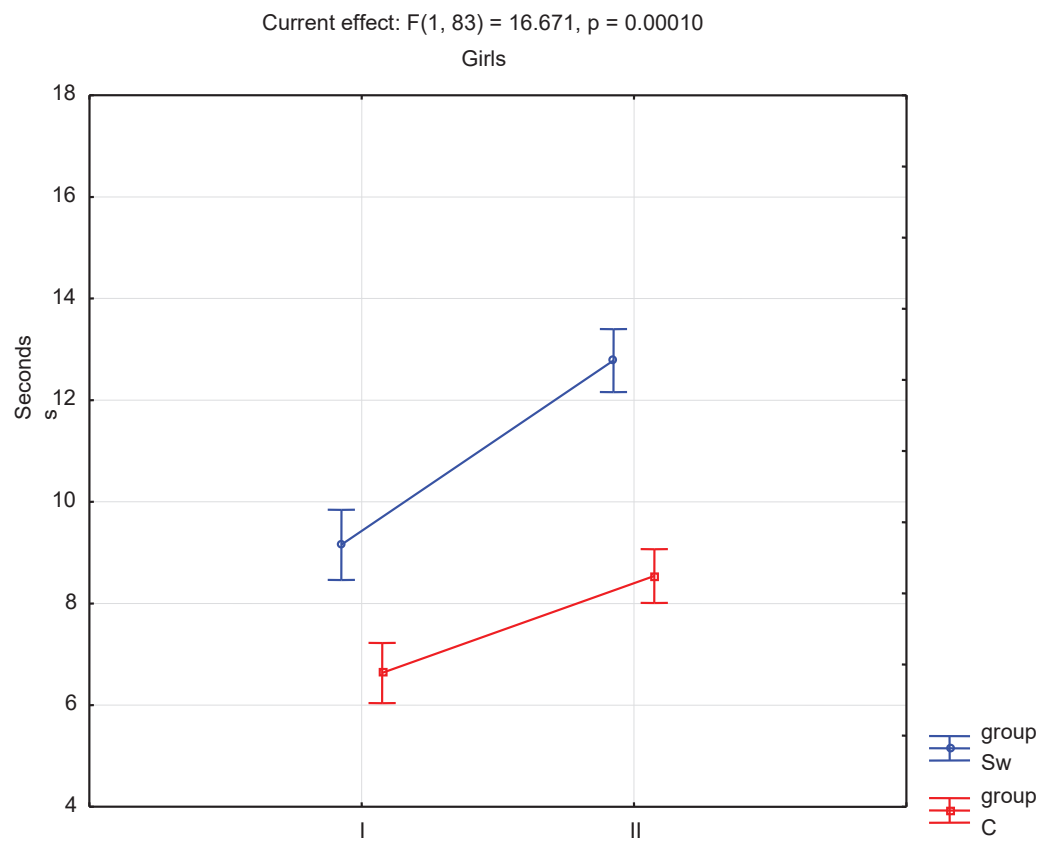

Figure 7. Changes is Bent Arm Hang Test (functional strength) results in the Swimmers (Sw) group and Control (C) group

\section{$10 \times 5 m$ Shuttle Run Test - agility Pun}

In Examination I, average results of the Shuttle Run were statistically insignificantly better in the Swimmers group, while in Examination II the statistical difference was significant. Examination II proved statistically significant improvement of results in both groups (Sw, C) in comparison to Examination I (Table 9). In the Swimmers group, it was on average $2.7 \mathrm{~s}$, while in the Control group it was $2.0 \mathrm{~s}(\mathrm{p}=0.036)$ (Figure 8).

Table 9. Descriptive characteristics of $10 \times 5 \mathrm{~m}$ Shuttle Run Test (agility run) results in the Swimmers (Sw) group and Control (C) group

\begin{tabular}{cccccccc} 
& \multirow{2}{*}{ Distribution type } & \multicolumn{3}{c}{ Examination I } & \multicolumn{2}{c}{ Examination II } & \multicolumn{2}{c}{ Examination I vs. Examination II } \\
\cline { 3 - 7 } & & Sw (seconds) & C (seconds) & Sw (seconds) & C (seconds) & Sw & C \\
\hline \multirow{4}{*}{ Girls } & 36 & 49 & 36 & 49 & & \\
& min-max & $20.7-37.4$ & $23.0-34.6$ & $19.2-35.9$ & $21.2-32.5$ & & \\
& mean & 26.1 & 27.2 & 23.5 & 25.1 & & \\
& $\bar{X}(\mathrm{SD})$ & $26.7(3.4)$ & $27.8(3.0)$ & $24.0(3.0)$ & $25.8(2.7)$ & $<.0001$ \\
\hline
\end{tabular}

Sw - Swimmers, C - Control, min - minimum value, max - maximum value, $\bar{X}$-arithmetic mean, SD - standard deviation, ss - statistical significance. 


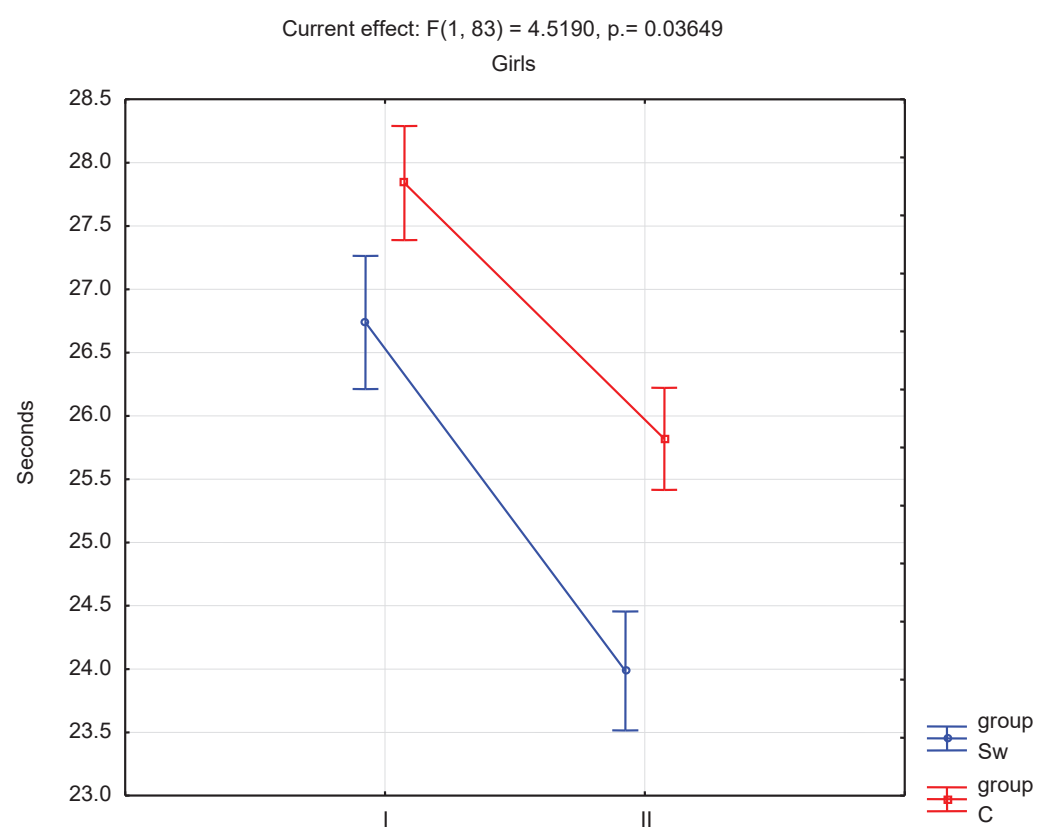

Figune 8. Changes in $10 \times 5 \mathrm{~m}$ Shuttle Run Test (agility run) results in the Swimmers (Sw) group and Control (C) group

\section{Discussion}

The research revealed changes in both groups (Sw, C) in terms of all eight tests. Examination II proved statistically significant improvement of results in both groups (Sw, C) in comparison to Examination I. Changes between Examination I and Examination II results were most visible in the Swimmers groups in terms of balance, agility, static strength, functional strength and agility run. Changes between Examination I and Examination II were similar in both groups $(\mathrm{Sw}, \mathrm{C})$ in terms of speed of limb movement, explosive strength and torso strength.

The analysis of statistical data from the EUROFIT Test Battery conducted by the author of this paper proved that the increased number of training hours resulted in enhanced motor skills in girls who started their swimming trainings. Other authors' research (Pietrusik, 1981; Dziedziczak, Witkowski, 1998) also indicated positive correlation between increased number of sports hours/trainings and motor skills of children who trained swimming.

Pietrusik's research (1981) confirmed that girls in swimming groups displayed significant improvements in final results of all physical ability tests (ICSPFT). There were no significant improvements in the examined motor skills (motor qualities) of subjects in control groups. It must be noted that the initial stage of school education is the period of significant development of all motor skills (Osiński, 2011), which was confirmed by Denisiuk, Milcerowa's (1969) research, conducted in the 1960s.

As for this study, the Swimmers group did not attain better dynamics of changes in all tests than the peer Control group (i.e. speed of upper limb movement, agility, explosive strength, torso strength, agility run). It may be explained by the specificity of swimming trainings: it was conducted at the swimming pool, not at the gym, which would increase strength of young swimmers more notably. 
Progressive changes in motor skill of subjects are a positive phenomenon in the physical development of a child. During both Examinations (I and II) subjects attended elementary school $1^{\text {st }}$ grade, i.e. the first grade of the early school age (Osiński, 2011). School authorities, Physical Education teachers and Integrated Education teachers at Elementary Schools no. 51, 55, 56 and 62 in Szczecin (attended by the subjects from both groups: Sw and C) facilitated the development of motor skills by their didactic, sports and recreational activities. Diversified motor and recreational activities provided during PE classes might have significantly influenced the EUROFIT Test results.

During both Examinations (I and II) subjects were $1^{\text {st }}$-graders, therefore their physical development was at an early school age, which lasts until puberty (at the age of 10-12) (Osiński, 2011). During this period, especially when children begin their school education, they must conform to certain requirements, school duties and new environment (Osiński, 2011). According to Przewęda (1981, p. 164) children display a great 'need to blow off steam by physical activity, to satisfy their great «hunger for activity».' Schools (their sports and recreational infrastructure), Physical Education teachers, Integrated (early age) education teachers influence the quality of motor skills development. Therefore, a Physical Education teacher plays a significant role in the process of physical development of the new generation. Participation in organized, regular sports classes results in the development of motor (physical) skills of children (Torrance, McGuire, Lewanczuk, McGavock, 2007; Chalcarz, Merkiel, Pach, Lasek, 2008; Wilk, Eider, 2014).

\section{Conclusions}

1. Examination II proved statistically significant improvement of results in both groups (Swimmers, Control) in comparison to Examination I.

2. Comparative analysis of motor skill of both groups confirmed that the dynamics of changes between Examinatioon I and II was greater among swimming subjects in five tests (general balance, agility, static strength, functional strength, agility run) (Figures 1, 3, 5, 7,8).

3. In the remaining motor skill tests (speed of upper limb movement, explosive strength, torso strength) differences in results between Examination I and Examination II were similar in both groups (Swimmers and Control group) (Figures 2, 4, 6).

4. Progressive changes in motor skill of subjects are a positive phenomenon in the physical development of a child.

5. Swimming training resulted significantly in positive changes in terms of motor skills of subject who were at the initial stage of swimming trainings, compared to their non-training peers.

6. Participation in organized, regular sports classes results in the development of motor (physical) skills of children.

\section{References}

Chalcarz, W., Merkiel, S., Pach, D., Lasak, Ż. (2008). Charakterystyka aktywności fizycznej poznańskich dzieci w wieku szkolnym. Medycyna Sportowa, 5 (24), 318-329.

Chomiak, J, Migasiewicz, J. (1998). Organizacja doboru i szkolenia dzieci uczęszczajacych do szkoły o profilu sportowym. In: P. Kowlaski, J. Migasiewicz (eds.), Sport pływacki i lekkoatletyczny w szkole (pp. 409-415) (Wrocław-Srebrna Góra 1996, 1997). Wrocław: AWF. 
Cięszczyk, P. (2005). Próba kompleksowej oceny doboru do sportu na przykładzie zespołowych gier sportowych. Antropomotoryka, 32, 59-71.

Cięszczyk, P. (2008). Efektywność przygotowania sprawnościowego na wstępnym etapie szkolenia, jako przesłanki racjonalizacji procesu treningowego w klasach sportowych o profilu zespołowych gier sportowych. International Association of Ontokinesiologist. Szczecin.

Eider, P. (2014). Selection in swimming traning- theoretical study. No. 1 in Szczecin. Centr Eur J Sport Sci., 1 (5), 65-75.

Denisiuk, L., Milicerowa, H. (1969). Rozwój sprawności motorycznej dzieci i młodzieży w wieku szkolnym. Warszawa: PZWS.

Dziedziczak, K., Witkowski, M. (1998). Rozwój fizyczny i sprawność fizyczna dzieci uprawiających pływanie. Wychowanie Fizyczne i Sport, 4, 13-20.

Grabowski, H., Szopa, J. (1991). EUROFIT. Europejski Test Sprawności Fizycznej. Kraków: AWF.

Karpiński, R., Opyrchał, C. (2008). Pływanie na Igrzyskach Olimpijskich w Pekinie - analiza poziomu sportowego, wieku i budowy somatycznej pływaków. Sport Wyczynowy, 10-12, 7-23.

Kolbowicz, M. (2012). Efektywność specjalnego przygotowania fizycznego w wieloletnim procesie szkolenia sportowego wioślarzy kadry olimpijskiej. Doctoral thesis typescript. Poznań: AWF.

Kosmol, A. (1997). Pływanie na Igrzyskach w Atlancie i Barcelonie. Sport Wyczynowy, 7-8, 9-24.

Opyrchał, C., Karpiński, R., Sachnowski, K. (2005). Proces wieloletniego szkolenia pływaków wysokiej klasy. Sport Wyczynowy, 9-10, 57-67.

Osiński, W. (2011). Teoria wychowania fizycznego. Poznań: AWF.

Pietrusik, K. (1981). Kształtowanie się sprawności motorycznej oraz wydolności fizycznej u dzieci uprawiających pływanie sportowe. Roczniki Naukowe AWF, 30, 107-125.

Przewęda, R. (1981). Rozwój somatyczny i motoryczny. Warszawa: WSiP.

Socha, S. (2008). Lekkoatletyka i pływanie na Igrzyskach Olimpijskich w Pekinie. Sport Wyczynowy, 10-12, 24-34.

Szopa, J., Chwała, W., Rychlewicz, T. (1998). Badania struktury zdolności motorycznych o podłożu energetycznym i trafność ich testowania. Antropomotoryka, 17, 3-41.

Torrance, B., McGuire, KA., Lewanczuk, R., McGavock, J. (2007). Overweight, physical activity and high blood pressure in children: a review literature. Vasc Health Risk Manag, 1 (3), 139-149.

Wilk K., Eider P. (2014) The evaluation of motor skills of 1-4 grade music-oriented male students in Primary School Complex. No. 2 in Szczecin. Centr Eur J Sport Sci., 2 (6), 35-58.

Cite this article aS: Eider, P., Wilk, K., Tarnowski, M., Terczyński, R. (2017). Changes in Motor Skills of Children who Train Sports Swimming at the Initial Stage of School Education (in an Annual Training Cycle). Central European Journal of Sport Sciences and Medicine, 4 (20), 93-105. DOI: 10.18276/cej.2017.4-10. 